\title{
The Precambrian of the Rocky Mountain Region
}

U.S. GEOLOGICAL SURVEY PROFESSIONAL PAPER 1241-D.

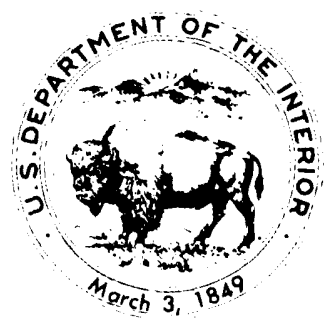




\section{The Precambrian of the Rocky Mountain Region}

By CARL E. HEDGE, ROBERT S. HOUSTON, OGDEN L. TWETO, ZELL E. PETERMAN, JACK E. HARRISON, and ROLLAND R. REID

CORRELATION OF PRECAMBRIAN ROCKS OF THE UNITED STATES AND MEXICO

Edited by JACK E. HARRISON and ZELL E. PETERMAN

U.S. GEOLOGICAL SURVEY PROFESSIONAL PAPER 1241-D

Lithology, distribution, correlation, and isotope ages of exposed Precambrian rocks in the Rocky Mountain region

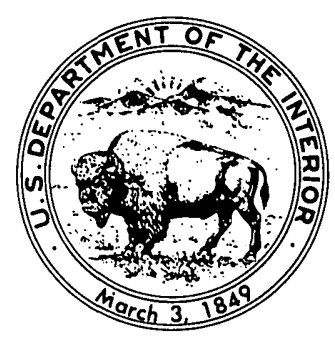

UNITED STATES GOVERNMENT PRINTING OFFICE, WASHINGTON : 1986 


\section{DEPARTMENT OF THE INTERIOR \\ DONALD PAUL HODEL, Secretary}

\section{U.S. GEOLOGICAL SURVEY}

Dallas L. Peck, Director

Library of Congress Cataloging in Publication Data

The Precambrian of the Rocky Mountain region.

(Correlation of Precambrian rocks of the United States and Mexico) (U.S. Geological Survey professional paper ; 1241-D)

Bibliography: p.

1. Geology, Stratigraphic-Pre-Cambrian. 2. Geology-Rocky Mountain Region.

I. Hedge, Carl E. II. Series. III. Series: Geological Survey professional paper ; 1241-D QE653.P734 1986 $551.7^{\prime} 1^{\prime} 0978$

For sale by the Branch of Distribution

Books and Open-File Reports Section

U.S. Geological Survey

Federal Center

Box 25425

Denver, CO 80225 


\section{CONTENTS}

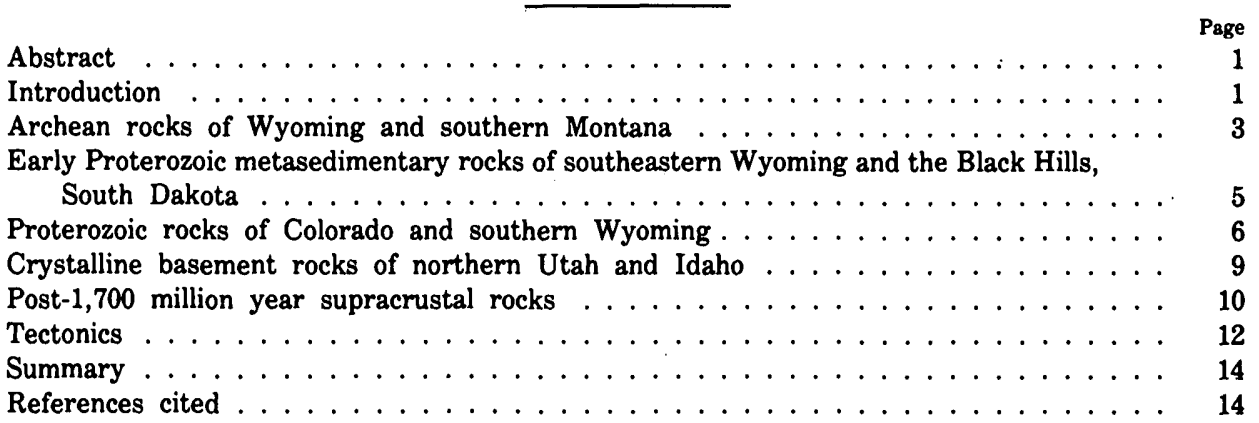

\section{ILLUSTRATIONS}

PLATE 1. Correlation chart for Precambrian rocks and events in the Rocky Mountain region.

FIGURE 1. Generalized geologic-geochronologic map of the Precambrian of the Rocky Mountain region . . . . . . . . . 2

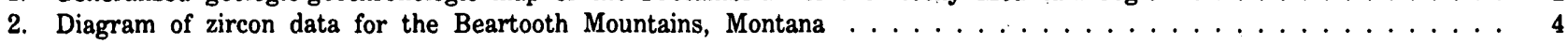

3. Geologic map of the Precambrian of Colorado and southernmost Wyoming . . . . . . . . . . . . . 8

4. Diagram of ages of approximately $1,670-$ m.y.-old plutons in Colorado . . . . . . . . . . . . . . . 9

5. Diagram of estimated ages of some events in the formation of the Belt Supergroup, Montana . . . . . . . . . 11

6. Map showing some Precambrian tectonic features in the Rocky Mountain region . . . . . . . . . . . . . 13 


\title{
THE PRECAMBRIAN OF THE ROCKY MOUNTAIN REGION
}

\author{
By Carl E. Hedge, Robert S. Houston ${ }^{1}$, Ogden L. Tweto, Zell E. Peterman, \\ JACK E. HARRISON, and ROLLAND R. REID ${ }^{2}$
}

\begin{abstract}
Precambrian crystalline rocks of the Rocky Mountain region of the United States represent two age provinces. An Archean province (older than 2,500 million years) occupies Wyoming and adjacent parts of Utah, Montana, and South Dakota. A Proterozoic province (about 1,600 to 1,800 million years old), is represented by only sparse exposures west and northwest of the older terrane, and by extensive exposures to the south. The Archean province is mostly felsic gneisses and associated metasedimentary rocks that were metamorphosed about 2,800 million years ago. Tonalitic to granodioritic plutons were emplaced in this terrane 2,500 to 2,760 million years ago.

In Colorado, a thick sequence of volcanic and sedimentary rocks was deposited between 2,000 and 1,750 million years ago. These rocks were metamorphosed and intruded by numerous granodioritic plutons about 1,700 million years ago. This province was invaded by granitic plutons 1,400 million years ago and again, in central Colorado, 1,015 million years ago.

Shelf-type sedimentary sequences were deposited on the older crust during the interval from 2,500 to 1,700 million years ago and are preserved in a belt from southern Wyoming to the Black Hills. A younger sequence, 1,460 to 1,600 million years in age, is preserved only as the Uncompahgre Formation in southwestern Colorado. A still younger sequence, the miogeoclinal Belt Supergroup, 850 to 1,500 million years in age, is preserved in western Montana and northern Idaho. Rocks roughly equivalent to but isolated from the Belt Supergroup include the Yellowjacket Formation and Lemhi Group of Idaho and the Uinta Mountain Group of northeastern Utah and northwestern Colorado. Eugeoclinal rocks, including diamictites, were deposited west of the miogeoclinal rocks beginning approximately 850 million years ago.
\end{abstract}

\section{INTRODUCTION}

Precambrian rocks are exposed in numerous areas in the Rocky Mountain region, mostly in the cores of uplifted mountain blocks (fig. 1). The rocks range from unmetamorphosed late Proterozoic sedimentary rocks to Archean gneisses. The state of knowledge of the geology and geochronology of the rocks varies widely through the region. In Colorado, abundant geochronologic data and extensive detailed field studies make possible the assignment of almost every Precambrian rock unit to a specific time period (Tweto, 1979).

\footnotetext{
'University of Wyoming, Laramie, Wyo.

${ }^{2}$ University of Idaho, Moscow, Idaho.
}

In contrast, the history of the pre-Belt basement rocks of western Montana and Idaho is only beginning to come into focus.

The earliest geologic work in the region established that the relatively unmetamorphosed sedimentary rocks, such as the Belt Supergroup and the Uinta Mountain Group, are younger than the crystalline complexes in many of the mountain ranges of Wyoming and Colorado. The advent of radiometric dating made possible studies that showed that the Precambrian crystalline rocks of most of Wyoming are older than those of Colorado. By the early 1960's, enough radiometric ages were available to show that the framework Precambrian rocks of Wyoming are of Archean age and are approximately equivalent to those of the Superior province of the Canadian Shield. Condie (1969) referred to the Archean terrane exposed mainly in Wyoming and southern Montana as the Wyoming province. In his reconstruction of the growth of the North American continent, Engel (1963) connected the Canadian and Wyoming terranes. Subsequent data from wells that penetrated basement rocks in the midcontinent region (Goldich and others, 1966) revealed, however, that younger rocks intervene between the two older terranes in the basement of western North and South Dakota.

The Archean of the Wyoming province extends into bordering States to the east, north, and west. Zartman and others (1964) demonstrated that Archean gneiss underlies the Precambrian metasedimentary rocks of the Black Hills, and Armstrong and Hills (1967) and Compton and others (1977) identified an Archean basement in northwestern Utah and south-central Idaho. Catanzaro and Kulp (1964) found the gneisses in the Little Belt Mountains of Montana to be of Archean age, and Peterman (1981) has demonstrated the extension of the Archean to the Little Rocky Mountains of northcentral Montana and into the basement of northeastern Wyoming.

To the south of the Wyoming province, no Archean 


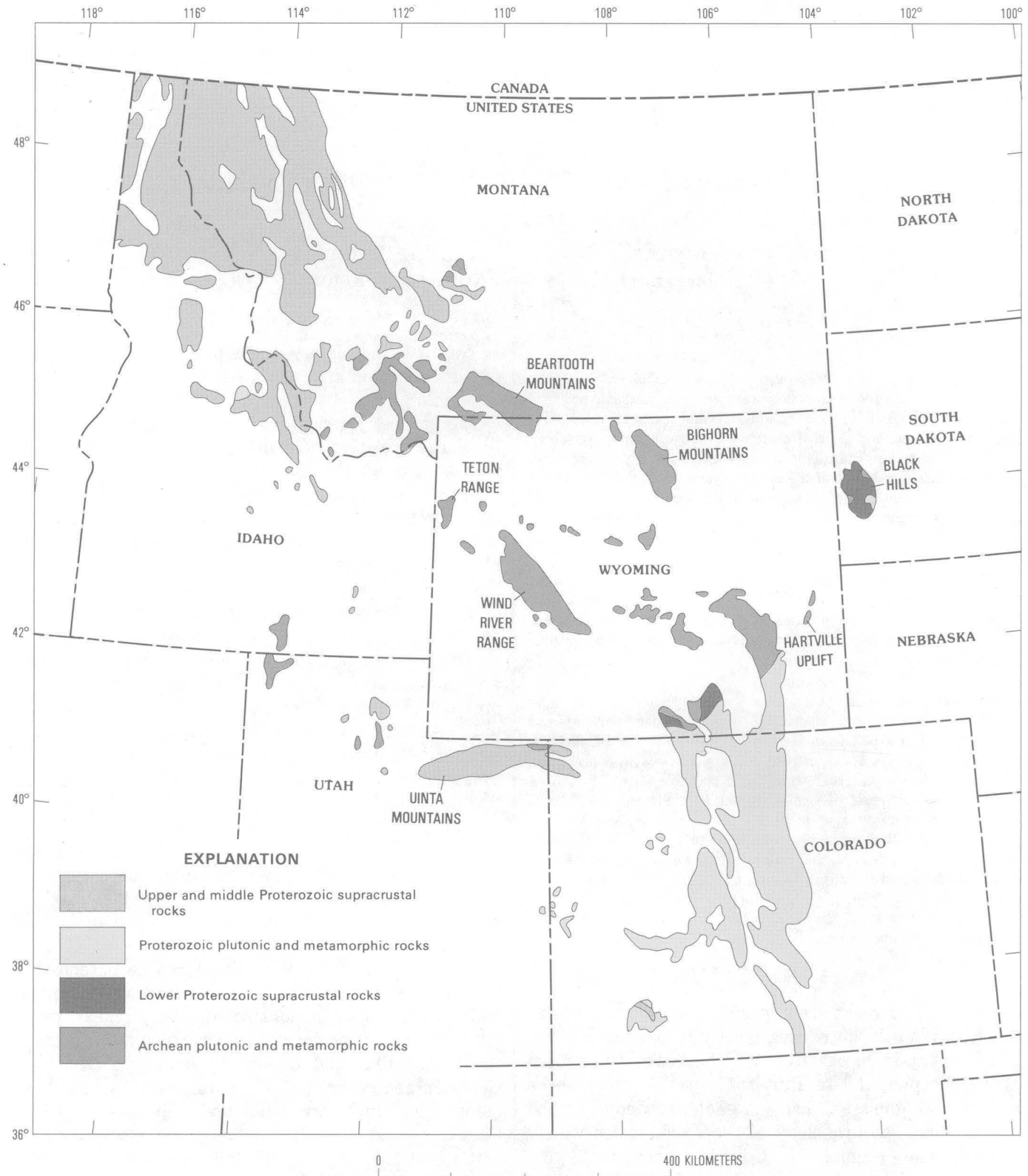

FigURE 1.-Generalized geologic-geochronologic map of the exposed Precambrian rocks of the Rocky Mountain region. 
rocks have been recognized. Extensive dating in Colorado has yielded no ages greater than about 1,850 m.y. (million years), and isotopic data strengthen the conclusion that the Precambrian of Colorado (and probably of large areas to the south and east) does in fact represent major new additions to the continent during the early Proterozoic.

The thick Precambrian sedimentary sections that occur along the western flank of the Rocky Mountains have been difficult to date, but considerable progress has been made, particularly with the Belt Supergroup, which was apparently deposited between 1,500 and 850 m.y. ago (Harrison, 1972).

Figure 1 provides a general overview of the timespace relationships of the exposed Precambrian rocks of the Rocky Mountain region. Plate 1 summarizes the chronologic knowledge of various areas or mountain ranges within the region.

\section{ARCHEAN ROCKS OF WYOMING AND SOUTHERN MONTANA}

The Archean terrane of the Wyoming province, although exposed mainly in the cores of mountain ranges in Wyoming and Montana (fig. 1), extends at least as far east as the Black Hills, as far west as the northwest corner of Utah, and northward to north-central Montana. In southeastern Wyoming, the Archean is overlapped by early Proterozoic supracrustal rocks and intruded by early and middle Proterozoic igneous rocks. Chronostratigraphic relations for Precambrian rocks exposed in the various ranges of the Wyoming province are shown on plate 1 . In most of these areas, late Archean granites were intruded into greenstone terranes and (or) gneiss complexes between about 2,500 and 2,700 m.y. ago. Earlier metamorphic and igneous events are recognized in some areas.

In comparison with the Archean of the Superior province of northern Minnesota and adjacent Ontario, the Wyoming province contains a much lower proportion of greenstone sequences. The best preserved greenstone terrane crops out at the southeast end of the Wind River Range (Bayley and others, 1973). Greenstones are also recognized in the Owl Creek Mountains (Granath, 1975), the Seminoe Mountains (Bayley, 1968), the central Laramie Range (Graff and others, 1982), and possibly in the Granite Mountains (Peterman and Hildreth, 1978).

Gneiss complexes occur throughout the Wyoming province and are the principal units in some of the ranges. These complexes include a variety of rock types commonly at a medium to high grade of metamorphism.
Some complexes are banded gneisses derived from stratified rocks, and others are massive and are probably orthogneisses. In some areas, interlayers of amphibolite, quartzite, and marble are common. In southwestern Montana, a gneiss complex contains abundant schistose rocks as well as quartzite, marble, and ironformation.

The oldest rocks thus far reported from the Wyoming province are in the Beartooth Mountains of southcentral Montana (pl. 1, G, H). The Beartooth Mountains consist of an older metamorphic complex, a younger group of metasedimentary rocks and more or less metamorphosed granitic rocks, the Stillwater Complex, and finally quartz monzonitic intrusions. Zircons from several of the older metamorphic units gave $U-P b$ (uranium-lead) isotopic results that define a good chord indicating an age of about $3,070 \mathrm{~m} . \mathrm{y}$. (fig. 2). This age is difficult to interpret: it may approximate the age of the source terranes from which the sediments were derived, or it may be the time of metamorphism. Mueller and others (1976) have interpreted U-Pb zircon data to indicate a history extending back to more than 3,300 m.y. in the eastern Beartooth Mountains. Metamorphism of the younger sedimentary sequence and intrusion of granitic rocks occurred about 2,750 m.y. ago in the Beartooth Mountains (Reid and others, 1975). The Stillwater Complex, a layered mafic complex, was emplaced just prior to 2,700 m.y. ago (Nunes and Tilton, 1971). Page (1977) concluded that a block containing the Stillwater Complex moved with respect to a southern block along a major fault; quartz monzonite dated at 2,700 m.y. is believed to have been injected along the fault zone.

The pre-Beltian rocks of all of southwestern Montana (pl. 1, F) probably have a history as complex as that of the Beartooth Mountains, but attempts to unravel the pre-2,730 m.y. history have failed thus far (Mueller and Cordua, 1976; James and Hedge, 1980). James and Hedge concluded that the terms Cherry Creek Group and Pony Group are of no value because both names are applied to rocks that can only be classified as parts of an Archean metamorphic complex.

Although the Precambrian rocks of the Bighorn Mountains (pl. 1, L) have thus far yielded no pre- 3,000 m.y. ages, Arth and others (1979) have dated a 3,000m.y. trondhjemitic intrusion and a 2,950-m.y. granodiorite in the southwestern part of the range. Banks and Heimlich (1976) and Heimlich and Banks (1968) reported an age of 2,850 m.y. for granites from the northern part of the range, and Stueber and Heimlich (1977) obtained an age of 2,760 m.y. for diabase dikes that cut these rocks. 


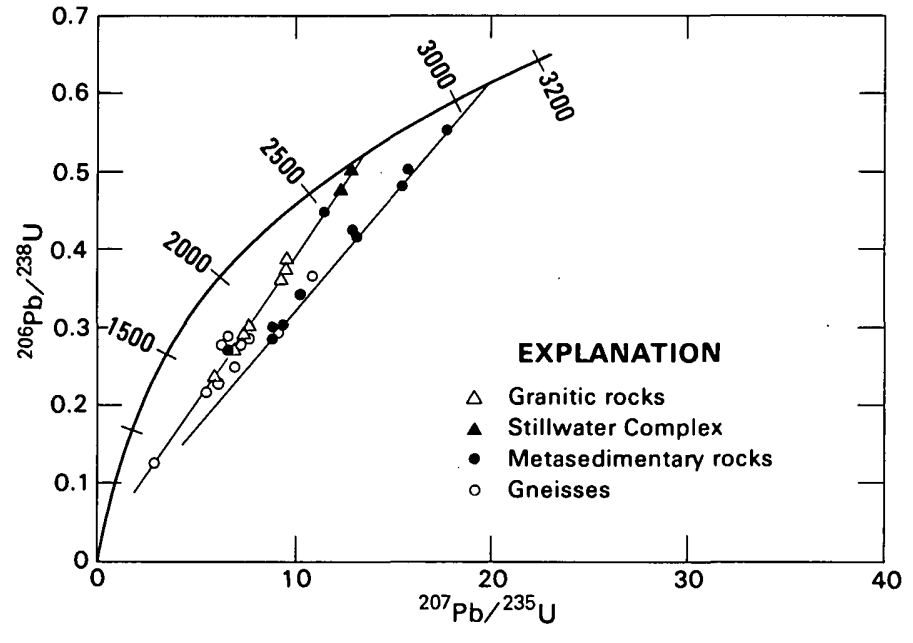

Figure 2.-Zircon data for the Beartooth Mountains, Mont. Data from Catanzaro and Kulp (1964), Nunes and Tilton (1971), and Reid and others (1975). Numbers on curve in millions of years.

In the Teton Range (pl. 1, I), Reed and Zartman (1973) assigned an age of metamorphism of 2,820 m.y. to the Webb Canyon Gneiss. They also reported an age of 2,440 m.y. for the Mount Owen Quartz Monzonite, but this latter age is suspect because of the improbably high initial ${ }^{87} \mathrm{Sr} /{ }^{86} \mathrm{Sr}$ ratio.

Two plutons in the Wind River Range (pl. 1, J), the Bears Ears pluton (Popo Agie batholith) and the Louis Lake Granodiorite, have been dated at 2,560 m.y. and $2,640 \mathrm{~m}$.y. respectively (Naylor and others, 1970). The Louis Lake Granodiorite intrudes the greenstone belt at South Pass, in the southeastern Wind River Range. A $\mathrm{Rb}-\mathrm{Sr}$ (rubidium-strontium) isochron age of 2,790 m.y. was obtained on metagraywacke and metavolcanic rocks within the greenstone belt, but the age has a large uncertainty (Z. E. Peterman, unpub. data, 1973). Similarly, five granitic gneiss samples from a gneiss complex in the central Wind River Range define a Rb$\mathrm{Sr}$ isochron age of 2,760 m.y. (Z. E. Peterman and Fred Barker, unpub. data, 1975).

An amphibolite-grade sedimentary-volcanic sequence in the Granite Mountains ( $\mathrm{pl} .1, \mathrm{M}$ ) of central Wyoming was metamorphosed at 2,860 m.y. (Peterman and Hildreth, 1978), and this unit may be equivalent to the greenstones at South Pass. The major granite batholith in the Granite Mountains has been dated at 2,550 m.y. by $\mathrm{Rb}-\mathrm{Sr}$ methods (Peterman and Hildreth, 1978) and at 2,590 m.y. by U-Pb methods on zircon (Ludwig and Stuckless, 1978). A small body of foliated granite gave an older $\mathrm{U}-\mathrm{Pb}$ age of $2,640 \mathrm{~m} . \mathrm{y}$. (Ludwig and Stuckless, 1978). The ages of the granitic intrusions are remarka- bly similar to those from the southeastern Wind River Range and suggest two discrete periods of regional plutonism.

Three whole-rock $\mathrm{Rb}-\mathrm{Sr}$ isochron ages have been reported (Johnson and Hills, 1976) for various gneiss units in the Laramie Mountains (pl. 1, N). These ages range from 2,700 m.y. to 2,960 m.y. A major batholith of granite was emplaced in the Laramie Mountains 2,510 m.y. ago (Hills and Armstrong, 1974; Johnson and Hills, 1976).

In the central Laramie Mountains (pl. 1, 0), the Elmers Rock greenstone belt (Graff and others, 1982) comprises late Archean metasedimentary and metavolcanic rocks. Zircons from metadacite are dated at about 2,720 m.y. (Z. E. Peterman, unpub. data, 1983). A similar sequence of metasedimentary and metavolcanic rocks in the Hartville uplift (pl. 1, R) is also late Archean and may be correlative with the sequence in the central Laramie Mountains (Snyder, 1980; Snyder and Peterman, 1982; Peterman, 1982). In the Hartville uplift, the supracrustal rocks are intruded by both late Archean and early Proterozoic rocks including the Rawhide Buttes Granite (2,580 m.y.), the Flattop Buttes Granite (1,980 m.y.), the Twin Hills Diorite (1,740 m.y.), and the Haystack Range Granite $(1,720$ m.y.).

Archean rocks are also exposed in the northern parts of the Medicine Bow Mountains and in the Sierra Madre of south-central Wyoming (pl. 1, P, Q). Again, an older gneissic complex was intruded by granites; however, the published ages are somewhat younger than those for similar rocks farther north. Hills and others (1968) reported a $\mathrm{Rb}-\mathrm{Sr}$ age of 2,500 m.y. for the granitic gneisses in the Medicine Bow Mountains, whereas Divis (1976) obtained a single zircon age of 2,630 m.y. in the Sierra Madre. Three ages on the Baggot Rocks Granite (Hills and others, 1968; Divis, 1976) range from 2,360 to $2,500 \mathrm{~m} . \mathrm{y}$. We are not certain whether these ages from southern Wyoming represent the true ages of the rocks, or whether the ages have been lowered somewhat by the metamorphic and igneous events just to the south.

A number of important mineral deposits are in these Archean rocks of Wyoming and Montana. These deposits include chromium, platinum, and nickel deposits of the Stillwater Complex, iron-formation in many of the greenstone belts, and gold in quartz veins and shear zones of the greenstone belts. Iron-formation described by Bayley and others (1973) is currently being mined in the Atlantic City region in the southeastern Wind River Range. 


\section{EARLY PROTEROZOIC METASEDIMENTARY ROCKS OF SOUTHEASTERN WYOMING AND THE BLACK HILLS, SOUTH DAKOTA}

Variably metamorphosed sedimentary rocks are preserved in a string of synclinoria or basins along the southern and eastern margins of the Wyoming Archean province (Hills and Houston, 1979). The most complete and best studied sequence preserved in Wyoming is in the Medicine Bow Mountains (Houston and others, 1968). The supracrustal rocks in the Medicine Bow Mountains consist of two sequences of strata separated by an angular unconformity. The lower sequence, which has been named the Deep Lake Formation, consists of at least $6,000 \mathrm{~m}$ of quartzite, metaconglomerate, chlorite schist, amygdular metabasalt, metatuff(?), and siliceous marble (Houston and others, 1968). Sericitic quartzite predominates. This very thick and compositionally variable formation contains strata representing many geologic environments, including probable glacial deposits as well as deposits of marine and fluviatile environments.

The Deep Lake Formation, currently being restudied, will be divided into two and possibly three subdivisions (Karlstrom and Houston, 1978; Houston and others, 1977). Deposition is cyclic, and the cyclic units resemble those described by Frarey and Roscoe (1970) in the Huronian Supergroup of Canada. In fact, radioactive quartz-pebble conglomerate has been recognized in rocks of the Deep Lake Formation (Houston and others, 1977; Graff and Houston, 1977) that may have been deposited in an oxygen-deficient environment like that suggested for radioactive quartz-pebble conglomerate of the Matinenda Formation of the Huronian Supergroup (Roscoe, 1973).

The Libby Creek Group, which consists of approximately $6,800 \mathrm{~m}$ of strata, overlies the Deep Lake Formation unconformably. The lower $3,700 \mathrm{~m}$ of this group is clastic sedimentary rock, of which about 60 percent is quartzite (in large part orthoquartzite) that has crossbeds and ripple marks, and most of the remainder of the group is micaceous quartzite and quartz-rich schist and phyllite. The basal formation of the Libby Creek Group, the Headquarters Schist, includes layers of fine-grained schist and phyllite that contain scattered boulders, cobbles, and pebbles. This formation may be partly of glacial origin (Houston and others, 1968). Above the quartz-rich lower part of the Libby Creek Group is the Nash Fork Formation, consisting of inter- bedded dolomitic marble that commonly contains algal structures (Knight and Keefer, 1966), and black phyllites and slates, some of which are pyritic and belong to the sulfide facies of iron-formation as defined by James (1954). The Nash Fork Formation and all lower formations in the Libby Creek Group are clearly of shallow-water origin and possibly of glacial origin in part, and we interpret them to be a shelf sequence.

The Towner Greenstone and the French Slate, the upper two formations of the Libby Creek Group, are of less certain interpretation; perhaps they record the beginning of a change in sedimentologic conditions along the edge of the formerly stable shelf. The Towner Greenstone consists mainly of chlorite-amphibolite schist in which rare thin beds of sandstone have been reported. Its origin is enigmatic, but it may consist of metamorphosed basic volcanic flows, basic pyroclastics, or both. The French Slate is a gray, pyritic slate or phyllite whose environment of deposition also is not well known.

The metasedimentary rocks in the other synclinoria are not as well known as those in the Medicine Bow Mountains. In the Sierra Madre, west of the Medicine Bow Mountains, a thick (probably more than $3,000 \mathrm{~m}$ ), unnamed sequence of mainly clastic metasedimentary rocks has been mapped (Houston and others, 1975). Micaceous quartzites predominate, but slate and phyllite are also abundant, and metavolcanic rocks, metalimestone, and metaconglomerate are present. Some of the metaconglomerates are possibly tillite, and some have the appearance of dropstone conglomerates. These strata probably correlate in part with the Deep Lake Formation of the Medicine Bow Mountains (Houston and others, 1968; Houston and others, 1975). Cyclic units like those identified in the Deep Lake Formation have been recognized in equivalent(?) rocks of the Sierra Madre, and radioactive quartz-pebble conglomerate has also been identified in these rocks (Graff and Houston, 1977), reinforcing the correlation with the Deep Lake Formation.

The metasedimentary rocks of the Black Hills (pl. 1, S) are more highly deformed and are of a higher metamorphic grade than the rocks of the Sierra Madre and Medicine Bow Mountains of Wyoming. Although many problems of correlation and structural complexity still exist, two maps that show subdivisions of the Precambrian of the entire Black Hills have been published (Redden and Norton, 1975; Kleinkopf and Redden, 1975). The lower part of the metasedimentary section is rich in quartzite but also contains metaconglomerate, schist, marble, and taconite iron-formation. These rocks 
are overlain by sequences that contain abundant amphibolite (metabasalt) and metagraywacke, which suggest a transition from a shelf-type environment to a more eugeoclinal type. What are apparently the youngest parts of the sequence are dominantly phyllites or schists and quartzites. It is perhaps significant that radioactive quartz-pebble conglomerate has been reported in the lower shelf-type environment of the Black Hills succession (Hills, 1977), but how these rocks may relate to similar shelf-type units of southeastern Wyoming or the Lake Superior region is not clear.

All that is known for certain about the age of this belt of supracrustal rocks is that it is younger than the Archean crystalline basement (2,500 m.y.) and older than about 1,700 m.y. This later age was suggested as the time of metamorphism in the Medicine Bow Mountains (Hills and others, 1968) and is the age of the Harney Peak Granite in the Black Hills (Riley, 1970). Hills and Houston (1979) have correlated various units of this supracrustal sequence with rocks of the Lake Superior region.

The early Proterozic metasedimentary rocks contain a number of major mining districts, and the potential for undiscovered mineral deposits is good. The extent of beds of iron-formation in the Black Hills, in particular, suggests that mining of these units will some day be feasible. Although it has been a point of long-standing controversy, recent studies concluded that the major Black Hills gold deposits are of Precambrian age (Redden and Norton, 1975; Rye and others, 1974). Copper was mined from deposits in metasedimentary rocks of the Sierra Madre of Wyoming at the turn of the century (Spencer, 1904). As mentioned earlier, this entire belt of metasedimentary rocks has potential for uranium. Radioactive quartz-pebble conglomerate has been found in the Black Hills, Sierra Madre, and Medicine Bow Mountains, and uranium is known to occur in faults and shear zones within the metasedimentary succession (Houston and others, 1977).

\section{PROTEROZOIC ROCKS OF COLORADO AND SOUTHERN WYOMING}

The Precambrian of Colorado consists mainly of a Proterozoic metamorphic complex extensively intruded by granitic rocks of three general age groups. The Archean rocks that underlie the Uinta Mountain Group in northeastern Utah extend only slightly into Colorado; all the other Precambrian rocks of Colorado are significantly younger.

The Precambrian metamorphic complex has been divided into two units, one consisting dominantly of metamorphosed sedimentary rocks and one consisting dominantly of metamorphosed volcanic rocks (Tweto,
1979). The metasedimentary rocks are mostly siliceous graywackes and shales, but they contain minor calcareous rocks and sandstone. The metavolcanic rocks seem to have been a bimodal suite of tholeiitic basalt and rhyodacitic tuffs and lavas. The metasedimentary and metavolcanic rocks are interlayered and intertongue on both regional and local scales (Tweto, 1977); however, the metavolcanic rocks predominate in southern and northern Colorado, and the metasedimentary rocks predominate in the central area (fig. 3).

The metamorphic rocks belong to the upper amphibolite facies over most of the State, but facies as low as lower amphibolite or as high as granulite exist locally. The pervasive regional metamorphism makes dating of the parent rocks difficult if not impossible. Silver and Barker (1968) obtained a U-Pb age of 1,800 m.y. on zircons from a metamorphosed volcanic rock in the Needle Mountains, and Hedge (unpub. data, 1979) got an identical age by $\mathrm{Rb}-\mathrm{Sr}$ on an only slightly metamorphosed rhyodacite tuff near Salida, Colo. Other attempts to obtain ages on the metamorphosed volcanic rocks have yielded figures of 1,700 to 1,750 m.y. using both $\mathrm{Rb}-\mathrm{Sr}$ and U-Pb methods. These apparent ages are indistinguishable from the time of regional metamorphism, and we believe that they are partly or totally reset ages.

Dating the time of deposition of the original sedimentary rocks is difficult because of the added possibility. of an inherited age component. Apparent $\mathrm{Rb}$-Sr ages of these rocks are mostly 1,700 to 1,750 m.y., but they are as much as 1,950 m.y. (Hedge and others, 1967; Peterman and others, 1968; Hansen and Peterman, 1968; and C. E. Hedge, unpub. data, 1979). Though many of these ages probably reflect the time of metamorphism, accumulation of the pile must have occurred sometime in the interval of 1,750 to 1,950 m.y., unless some metamorphic mechanism caused massive removal of radiogenic strontium from the entire complex on a regional scale.

Several stages of the major period of metamorphism and deformation are recognized in most Colorado localities. These cannot be differentiated by radiometric dating techniques, and they are inferred to have been closely spaced in time.

During the later stages of early Proterozoic regional metamorphism, numerous batholiths and smaller plutons were emplaced throughout the State. These range in composition from gabbro to granite, but granodiorite predominates. Most of these plutons are foliated, with internal structures parallel to those of the metamorphic wall rocks. Varied relations of the igneous bodies to the structure of the enclosing gneisses indicate emplacement over a period of time during the waning stages of metamorphism and deformation. Radiometric 
dating has failed to resolve any differences in the ages of the plutons, however, and all of them appear to have been emplaced about 1,670 m.y. ago (fig. 4). One of the youngest phases of this early plutonic event is represented by lamprophyre dikes in the Front Range west of Denver. These dikes are undeformed, are only slightly metamorphosed, and are cut by undeformed pegmatites that have been dated at 1,620 m.y. (C. E. Hedge, unpub. data, 1979).

After these intrusive and metamorphic events and before another intrusive episode about 1,430 m.y. ago, sediments of the Uncompahgre Formation were deposited in southwestern Colorado. The sediments were folded and metamorphosed to slates, phyllites, and quartzites and were then intruded by granite of 1,435 m.y. age. Rocks equivalent to the Uncompahgre are not known elsewhere in the Rocky Mountain region, but abundant clasts of chlorite phyllite in the Pennsylvanian Minturn Formation suggest that some may have existed in the west-central part of the Front Range as late as Pennsylvanian time.

Throughout the rest of the State, the geologic record is missing for a period of $200-250 \mathrm{~m} . \mathrm{y}$. prior to about 1,430 m.y., when a major period of granite emplacement began. Plutons of this period were apparently intruded at a higher crustal level than those of the 1,670m.y. period (Hutchinson and Hedge, 1967). They occur in a wide belt that extends from northwestern Mexico to the Great Lakes region. Within Colorado the granites are of two different types, which occupy distinct geographic areas (fig. 3), and seem to be slightly different in age. The first type is exemplified by the Sherman Granite of northern Colorado and southern Wyoming and the Eolus Granite of southwestern Colorado. These rocks are massive, are generally red or pink, contain blocky microcline crystals, and commonly contain hornblende as well as biotite. In several localities these granites are associated with syenites, and the ${ }^{207} \mathrm{~Pb} /{ }^{206} \mathrm{~Pb}$ age of the Sherman Granite is indistinguishable from that of the adjacent Laramie Anorthosite. The Sherman Granite is 1,435 m.y. old (Subbarayudu and others, 1975). A similar rock, the granite of the Mount Ethel pluton in the Park Range, yielded an age of 1,440 m.y. (Snyder and Hedge, 1978). The Eolus Granite in southwestern Colorado has been dated at 1,435 m.y. (Bickford and others, 1969), and similar rocks in west-central Colorado have given an age of 1,430 m.y. (Bickford and Cudzilo, 1975). The second type of approximately $1,430 \mathrm{~m} . \mathrm{y}$. granite is represented by the Silver Plume Granite, which occurs in the central part of the State (fig. 3). This rock is gray to light pink and is characterized by two micas and by microcline crystals that are distinctly tabular. Rocks of this type have yielded ages of about $1,400-1,410 \mathrm{~m} . \mathrm{y}$.
(Peterman and others, 1968; Doe and Pearson, 1969; Hansen and Peterman, 1968; and Stern and others, 1971).

The Pikes Peak batholith was emplaced 1,015 m.y. ago (Hedge, 1970; Barker and others, 1976). It is a large $\left(3,400 \mathrm{~km}^{2}\right)$ composite batholith that consists principally of potassic granite but also contains fayalite granite, syenite, and gabbro and associated small plutons and ring complexes (Hutchinson, 1976; Wobus, 1976). Unlike the granites of the two earlier periods of plutonism, the Pikes Peak Granite occurs only in a single batholith, and except for a few dikes no other rocks of this age are exposed in the State. The Pikes Peak batholith was probably emplaced at even shallower levels than the $1,400-\mathrm{m} . \mathrm{y}$. plutons (Hutchinson and Hedge, 1976).

Throughout most of the State, no geologic record is preserved for the interval between $1,400 \mathrm{~m} . \mathrm{y}$. and $1,015 \mathrm{~m} . \mathrm{y}$. The single exception is in extreme northwestern Colorado, where the Uinta Mountain Group extends in from Utah. This thick sequence of quartzite, shale, and conglomerate was apparently deposited between 1,440 and $950 \mathrm{~m} . \mathrm{y}$. ago; it is discussed later in this report.

An important economic aspect of the Precambrian rocks in Colorado is the role of northeast-trending shear zones in setting the stage for Laramide and younger mineralization of the Colorado mineral belt (Tweto and Sims, 1963). In addition, many kinds of economic mineral occurrences of Precambrian age exist. None of these have thus far been highly productive, but they point to the possibility of the existence of more significant deposits. Noteworthy is the recognition of gahnite, the zinc spinel, as a metamorphic component of gneisses in several localities (Sheridan and Raymond, 1977). The gahnite sometimes occurs with metamorphic base-metal sulfides but also is found in the absence of sulfides, principally in metavolcanic rocks. Numerous Precambrian sulfide deposits have been worked or prospected in the State (Tweto, 1968). In addition to base metals, these deposits contain gold and silver, and some contain molybdenum, tungsten, or nickel. Metamorphic scheelite and powellite occur in calc-silicate rocks in several localities (Tweto, 1960). Rutile occurs in economic amounts (as much as 5 percent) in sillimanitic topaz-quartz gneiss in a lengthy belt in the east-central Front Range (Marsh and Sheridan, 1976). Xenotime and monazite constitute as much as 5 percent by volume of migmatized biotite gneiss in the Central City area of the Front Range (Young and Sims, 1971). Uraninite is disseminated in migmatized biotite gneiss in the west-central Front Range and is of about the same age as nearby granite of the 1,400m.y.-age group (Young, 1975). Pegmatites valuable for 


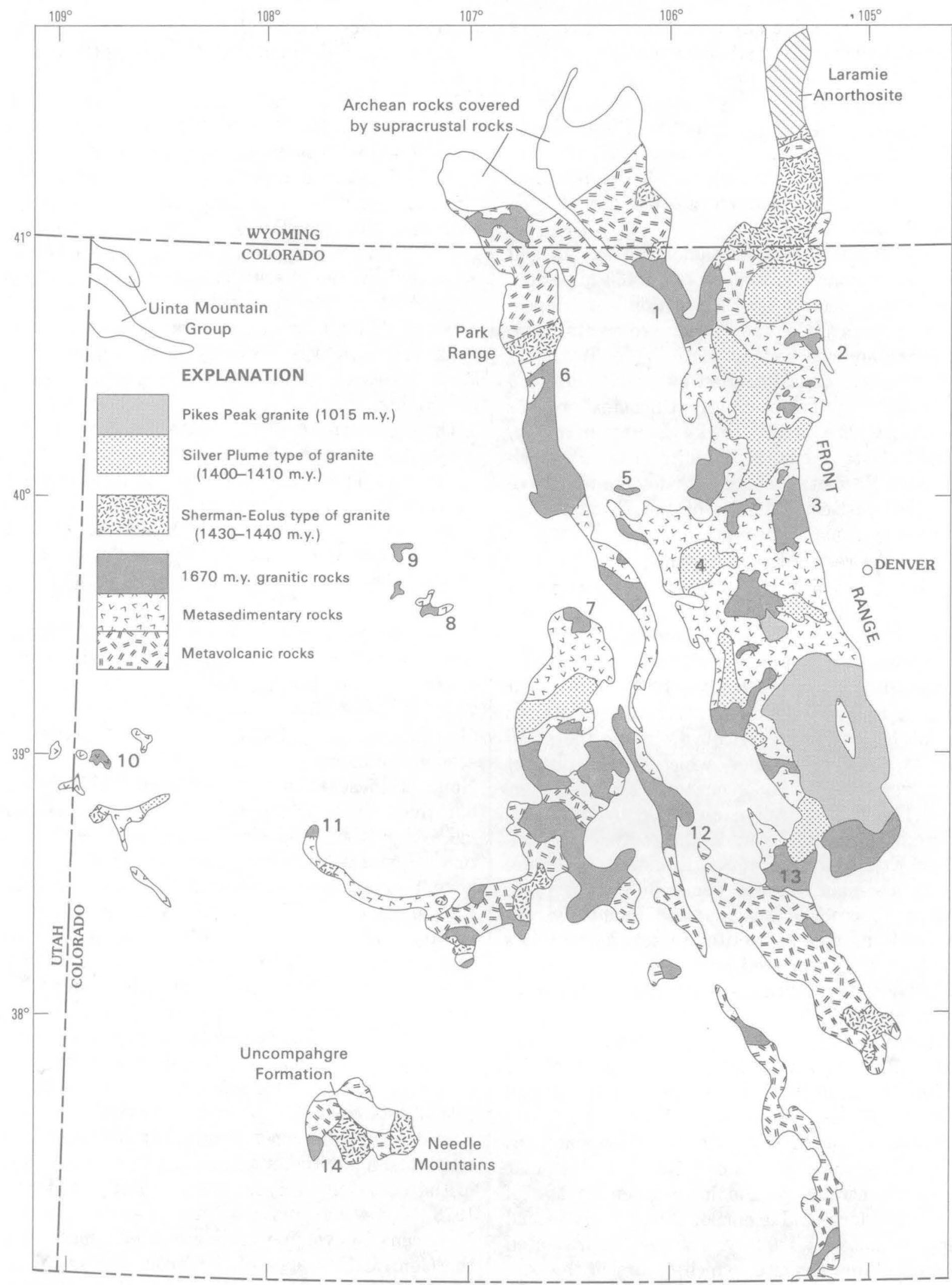

0100 KILOMETERS

Figure 3,-Geologic map of the Precambrian of Colorado and southernmost Wyoming. Numbers refer to radiometrically dated 1,670-m.y. plutons shown on figure 4. 


\begin{tabular}{|c|c|c|c|c|c|c|}
\hline MAP NO. & UNIT OR LOCALITY & REFERENCES & \multicolumn{4}{|c|}{ AGE } \\
\hline & & & 1500 & 1600 & 1700 & 1800 m.y. \\
\hline 1 & Rawah batholith & 1 & & & 7 & \\
\hline 2 & Northern Front Range & 2 & & & $z$ & \\
\hline 3 & Boulder Creek Granodiorite & 2.3 & & & 7 & \\
\hline 4 & Mount Evans & 4 & & ह7ग & & \\
\hline 5 & Byers Canyon & 5 & & & 720 & \\
\hline 6 & Buffalo Pass & 6 & & & $Z 772$ & \\
\hline 7 & Cross Creek Granite & 6 & & & 7277 & \\
\hline 8 & Glenwood Canyon & 6 & & & 20 & \\
\hline 9 & White River uplift & 6 & & & 72 & \\
\hline 10 & Uncompahgre uplift & 7 & & $\mathbb{Z Z}$ & & \\
\hline 11 & Black Canyon & 8 & & & 7171 & \\
\hline 12 & Salida & 6 & & & & \\
\hline 13 & Arkansas River & 6 & & & 乙 & \\
\hline 14 & Needle Mountains & 9,10 & & & & \\
\hline
\end{tabular}

FIGURE 4.-Ages of approximately 1,670 m.y. plutons in Colorado. Bar indicates range. Localities are shown on figure 3. References are: 1, McCallum and Hedge (1976); 2, Peterman and others (1968); 3, Stern and others (1971); 4, Bryant and Hedge (1978); 5, Izett (1968); 6, Snyder and Hedge (1978); 7, C. E. Hedge, unpub. data, 1979; 8, Hedge and others (1968); 9, Hansen and Peterman (1968); 10, Bickford and others (1969).

minerals such as beryl, mica, and spodumene are associated with granites of the 1,400-m.y. group, and beryllium-bearing greisen pipes accompany a late phase of the Pikes Peak batholith. Thorium veins and vanadium-bearing titaniferous magnetite are associated with an alkalic intrusive center in southwestern Colorado that is on the borderline between Precambrian and Cambrian in age (Olson and others, 1977).

\section{CRYSTALLINE BASEMENT ROCKS OF NORTHERN UTAH AND IDAHO}

The crystalline basement rocks of northern Utah and Idaho are poorly understood because of the very limited exposures and the intensity of younger geologic events. (See pl. 1, A-C.) Archean rocks occur as far west as northwestern Utah and south-central Idaho, where they appear in the cores of gneiss domes (Armstrong, 1968; Compton and others, 1977). In northeastern Utah the Uinta Mountain Group was deposited on the Red Creek Quartzite. The Red Creek is dominantly quartzite, but schist and amphibolite are also common. These rocks have been metamorphosed to amphibolite facies. Muscovite from the Red Creek Quartzite has given a $\mathrm{Rb}-\mathrm{Sr}$ age of 2,400 m.y. (Hansen, 1965), and because this may be a minimum age (the muscovite gave a K-Ar (potassium-argon) age of 1,500 m.y.), the Red Creek should probably be assigned to the Archean.

Only K-Ar mineral dates are available for the Precambrian crystalline rocks of the Wasatch Mountains and Antelope Island, in the Great Salt Lake; these are no older than about 1,600 m.y. (Whelan, 1969). However, $\mathrm{Pb}$-isotopic data presented by Stacey and others (1968) for ore leads in this region afford conclusive evidence of the existence of an Archean basement. Unpublished data (C. E. Hedge, J. S. Stacey, and B. R. Bryant, 1980) indicate that the Wasatch Mountains contain Archean gneisses and an 1,850-m.y.-old granite.

In central Idaho, along the eastern margin of the Idaho batholith, Belt rocks have been metamorphosed to a high grade and tectonically mixed with the preBelt basement rocks. Neither the geologic nor the geochronologic data are yet adequate to separate the mixed rocks with certainty at many exposures. The pre-Belt Boehls Butte Anorthosite has yielded a U-Pb zircon age of 1,625 m.y., and the Boehls Butte Formation, which the anorthosite intrudes, gave a zircon age of 1,665 m.y. (Reid and others, 1973); these data were interpreted as being minimum ages for these units. Armstrong (1975) concluded that the orthogneiss along the Salmon River is at least 1,500 m.y. old. Clark (1973) reported an age of 1,540 m.y. for orthogneisses 
in northern Idaho that are also interpreted as being pre-Belt.

\section{POST-1,700 MILLION YEAR SUPRACRUSTAL ROCKS}

The west edge of the Rocky Mountain region became the western continental margin about 1,700-1,600 m.y. ago. Three sedimentary sequences were deposited westward into probable marine basins underlain by rocks as old as $2,400+$ m.y. and as young as 1,700 m.y.

The oldest sequence, the Uncompahgre Formation of southwestern Colorado (pl. 1, V) was deposited between 1,600 and 1,450 m.y. ago (Barker, 1969). The erosional remnant of the formation has a relatively small areal extent (fig. 3). Barker (1969) described the rocks as consisting mostly of crossbedded quartzite plus minor amounts of conglomerate, slate, phyllite, and schist that have a total thickness of perhaps $2,450 \mathrm{~m}$. The depositional environment of the formation is not certain. The rocks were metamorphosed and folded before being intruded by granite 1,435 m.y. ago.

The next younger sedimentary-rock sequences of the Rocky Mountain region are the Uinta Mountain Group of northeastern Utah and northwestern Colorado (fig. 3 ) and the Belt Supergroup and equivalents of western Montana, northern Idaho, and northeastern Washington (fig. 1). These and other sedimentary sequences in Alaska, Canada, and Western and Northwestern United States appear to have been deposited in response to tectonic-magmatic events about 1,400 1,500 m.y. ago. This sedimentation cycle is punctuated by igneous activity that produced small amounts of anorogenic granite, basic sills in extension fractures, and minor amounts of lava at about 1,100 m.y.; the cycle terminated about $850 \pm 50 \mathrm{~m}$.y. ago in most areas.

Within the Rocky Mountain region, the southernmost sedimentary sequence of this cycle is the Uinta Mountain Group (pl. 1, A). Rocks of the group are exposed along an east-trending Phanerozoic arch and continue eastward in the subsurface. The rocks are almost unmetamorphosed and undeformed, and they consist principally of about $7,900 \mathrm{~m}$ of red to brown slightly feldspathic quartzites, olive-drab shales, and small amounts of red or black shale (Hansen, 1965). They represent fluvial sediments transported from the north and northeast across a strandline, along with nearshore marine and deltaic deposits formed by westward transport in the basin (Wallace and Crittenden, 1969). The north edge of the basin is reasonably well defined and may represent a Precambrian fault that was reactivated in the Phanerozoic, helping to form the prominent west-trending Uinta Mountains; the south edge of the Precambrian basin is eroded and cannot be defined.
The age of the Uinta Mountain Group is bracketed between 1,440 and $950 \mathrm{~m} . \mathrm{y}$. In northeastern Utah, the basal rocks were deposited unconformably on the Red Creek Quartzite. Muscovite from the quartzite gives a $\mathrm{Rb}-\mathrm{Sr}$ age of 2,400 m.y. (Hansen, 1965), but K-Ar ages also record another event at about 1,500 m.y. An even younger maximum age is suggested by the undeformed rocks in the subsurface that extend eastward into Colorado almost to the Park Range, where a large pluton of 1,440-m.y.-old granite is exposed. Thus it seems unlikely that the deposition of the undeformed Uinta Mountain Group began before 1,440 m.y. ago. A minimum age of $950 \mathrm{~m}$.y. for the group is given by a wholerock $\mathrm{Rb}$-Sr age determination on the uppermost formation (Red Pine Shale) (Crittenden and Peterman, 1975).

The most extensive exposures of sedimentary rocks deposited during the cycle from 1,500 to 850 m.y. ago are of the Belt Supergroup (Purcell Supergroup of Canada) in western Montana, northern Idaho, and eastern Washington, and their probable correlatives in east-central Idaho (pl. 1, B-D). Belt sediments at least $20 \mathrm{~km}$ thick accumulated in an epicratonic reentrant presumably connected to the Cordilleran miogeocline on the west (Harrison and others, 1974). The rocks are relatively undeformed except near the edges of the exposed Belt terrane; metamorphism ranges from almost none at the top of the section, to biotite grade at the bottom, to amphibolite grade near plutons of Cretaceous-Tertiary age.

Sedimentation within the Belt basin was in four major cycles of marine or marginal marine clastic and carbonate sediments that accumulated without apparent widespread interruptions (fig. 5). Early deposits (Prichard Formation) contain abundant turbidites, and the first cycle was terminated by a black shale (Edmunds, 1973). Subsequent deposits are dominantly redbed sequences and carbonates. The second cycle (Ravalli Group) is represented by a deltaic sequence prograded from the south (Hrabar, 1971) that interfingers with a probable delta complex built southwestward from the Canadian Shield. The third cycle is a carbonate sequence that contains shelf-type carbonates and evidence of periodic hypersaline conditions (Eby, 1977) in the east and northeast. These rocks grade westward into a more clastic carbonate-bearing section that contains a zone of slope breccias and large slumps; this section had a southern source terrane. The fourth cycle (Missoula Group) consists mostly of clastic redbed sequences prograded into the basin from both the south and the northeast. The middle part of this cycle has been interpreted by Winston (1973) as deposits of braided streams, alluvial fans, and associated shallowwater facies.

A general history of Belt events (fig. 5) was pre- 


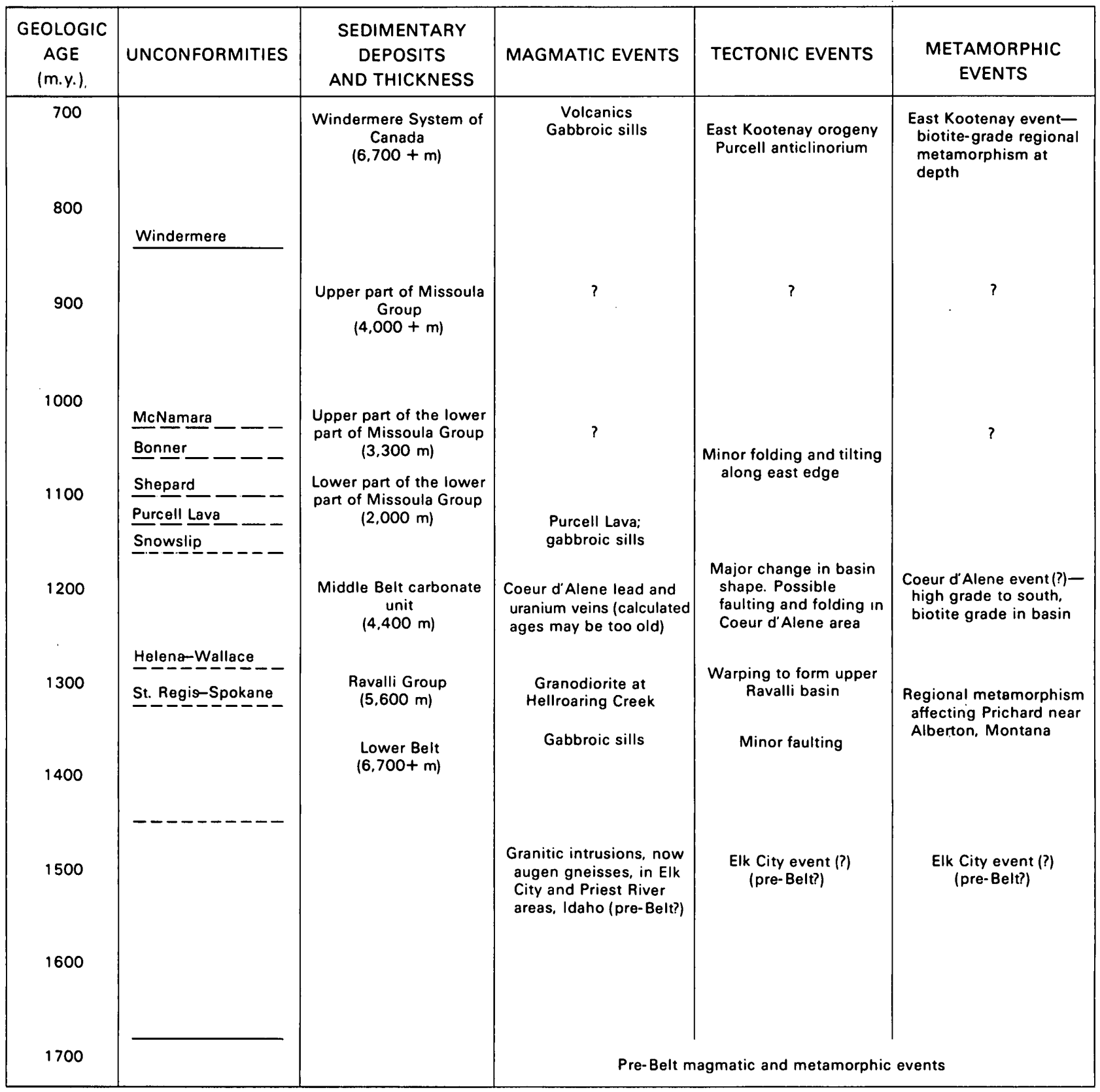

Figure 5.-Estimated ages of some events in the formation of the Belt Supergroup, Montana. Modified from Harrison (1972). Extent of unconformities: solid line, basinwide; long dashed line, local; short dashed line, inferred. Queries indicate uncertainty in either occurrence or age of an event.

sented by Harrison (1972) and is only slightly modified as reproduced here. Many of the problems of dating events and rock bodies within this sequence are still unresolved. The maximum age of the Belt Supergroup, as indicated by mica ages from the basement in Montana and Canada, is about 1,700 m.y. In Idaho, rocks as young as $1,500 \mathrm{~m} . \mathrm{y}$. may be the basement upon which the Belt was deposited. The minimum age is loosely established by a series of magmatic and tectonic events (the East Kootenay orogeny) ranging in age from about 870 to $725 \mathrm{~m} . \mathrm{y}$.

Probable correlatives of Belt rocks in east-central Idaho include about $12,000 \mathrm{~m}$ of clastic rocks called the Yellowjacket and Hoodoo Formations, the Lemhi Group, and the Swauger Formation. Although the Yellowjacket Formation resembles the Prichard Formation, the lower formations of the Lemhi Group resemble the Ravalli Group, and the Swauger resembles some 
rocks of the Missoula Group, the middle 6,000 m only vaguely resemble Belt rocks and no major carbonate unit is present. Ruppel (1975) suggested that although the rocks may be Belt in age, the Lemhi Group and Swauger Formation lie on thrust plates that have been translated to the east perhaps as much as $160 \mathrm{~km}$ and therefore represent deposits of the Cordilleran miogeocline now telescoped into juxtaposition with rocks of the Belt basin. Zircon suites from cogenetic plutons that intrude the upper Yellowjacket Formation yield an age of $1,370 \pm 10 \mathrm{~m} . \mathrm{y}$., which suggests that the Yellowjacket is a time correlative of the Prichard (Evans, 1981).

Rocks of the cycle from 1,500 to 850 m.y. ago host a variety of ore deposits of Precambrian age. The unique lead-silver veins of the Coeur d'Alene mining district, Idaho, are on the west end of a zone of crustal weakness that was active as a trough during Belt sedimentation and was the site of some local faulting (Chevillon, 1977). Ores that include a few early uranium-bearing veins were emplaced after tight upright to overturned folding occurred (Hobbs and others, 1965), called by some the Coeur d'Alene event (fig. 5). Although isotopic data have been interpreted to show that the ores are about 1,200 m.y. old (Zartman and Stacey, 1971), no evidence of a major disturbance has been found in the sedimentation record for that time as yet, and a permissive isotopic age of about $850 \mathrm{~m} . \mathrm{y}$. cannot yet be excluded.

Stratabound ores of two types are known in Belt age rocks. The most famous are Sullivan-type lead-zinc ores that occur in Canada in the lower Belt equivalent (Aldridge Formation). Recent sulfur isotope studies (Campbell and others, 1978) combined with previous geologic studies indicate that the ore was deposited from upwelling metalliferous solutions entering restricted seafloor basins formed by faulting penecontemporaneous with sedimentation. Such euxinic basins are apparently characteristic of the first cycle of Belt and Yellowjacket sedimentation, and the search for geologic characteristics indicative of penecontemporaneous faulting during deposition has become a major prospecting tool in these units.

Copper-silver stratabound ores and occurrences are common in the clastic rocks of the 1,500-850 m.y. ago cycle. The most abundant occurrences have been described by Harrison (1974) as limited to green beds in red-bed sequences and to nonoxidized quartzites of the Belt Supergroup. Although copper deposits were formed during diagenesis, Harrison (1974) suggested that subsequent remobilization from the original sedimentary traps was essential to form ores in permeable strata. Subeconomic occurrences of copper and silver are also known from the reduced (green or black) clastic strata of the Lemhi and Uinta Mountain Groups.

The final cycle of the late Proterozoic deposition lasted from about 950 m.y. through the Early Cambrian (about 540 m.y.). The rock sequences are characterized particularly by diamictites and eruptive volcanics as well as marine clastics and carbonates, and they were deposited unconformably on and seaward of the previous rock sequences. Very limited exposures of these rocks occur in the Rocky Mountain region, principally in eastern Washington and southeastern Idaho; they and their equivalents are correlated with the Windermere Supergroup of Canada. The rock sequence has been interpreted as representing initial deposits in a rift formed by continental separation that began about 850 m.y. ago (Stewart, 1976). An alternative hypothesis is that these and other late Proterozoic rocks of the previous cycle were deposited on a stable platform (trailing edge) in response to dominantly vertical tectonic movements (Harrison and Reynolds, 1976).

\section{TECTONICS}

Interpretations of Precambrian tectonic activity in the Rocky Mountain region are constrained by the limited and isolated exposures of Precambrian rocks and by the fact that these exposures result from Laramide tectonics that commonly were superimposed on reactivated Precambrian features. In places, even the Laramide tectonics are not yet completely understood.

All the Precambrian metamorphic rocks were complexly folded and many show multiple deformations. No regional stress directions are obvious from this folding. Some foldings or refoldings clearly were in response to local stresses around intruding granitic plutons and are not necessarily related to regional patterns.

The importance of Precambrian faults and shear zones on subsequent geologic history cannot be overemphasized, and this subject deserves much more work. Many of these Precambrian tectonic elements have now been identified (fig. 6) and for some of them the time and sense of movement are known.

Much of the Laramide-age Colorado mineral belt (fig. 6, A) parallels a system of Precambrian shear zones (Tweto and Sims, 1963). These shear zones were active at least from the time of the 1,430-m.y. plutonic event onward, though they could have had an earlier history. Aside from the shear zones, the Precambrian fracture pattern is dominated by faults of north-northwest trend. These faults created a grain that persists to this day in the geology and topography of the mountain province in Colorado. Some of the faults were in existence before the 1,670-m.y. granites were emplaced, and some are occupied by mafic to intermediate dikes of 


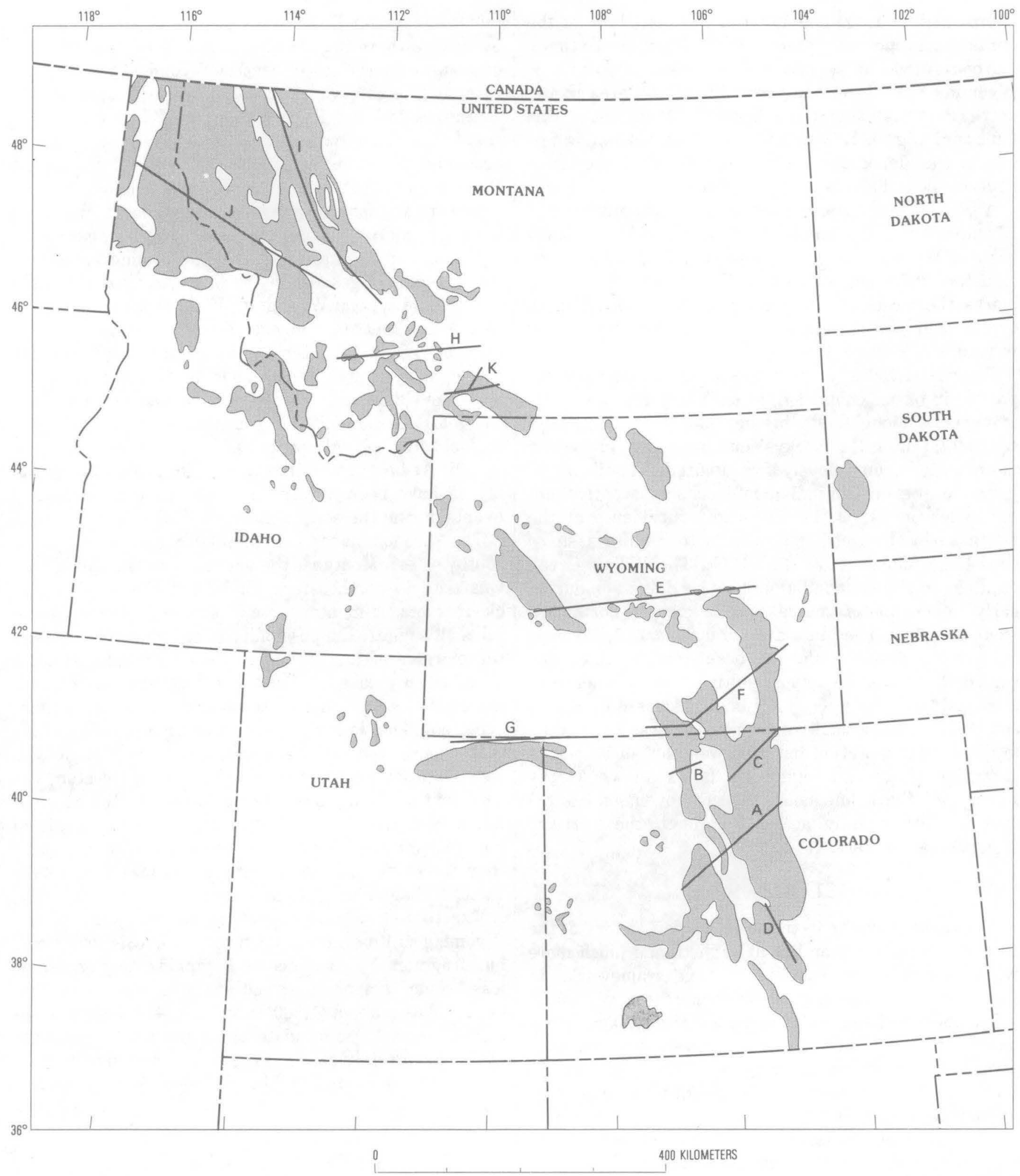

FigURE 6.-Some Precambrian tectonic features in the Rocky Mountain region. Pattern, exposed Precambrian. A, Shear zone that defined trend of Colorado mineral belt (Tweto and Sims, 1963); B, Precambrian shear zones (Snyder, 1978); C, Shear zone that controls minor Tertiary igneous activity and mineralization (Abbott, 1962); D, Ilse fault zone (Scott and others, 1976); E, Discontinuity in K-Ar ages (Peterman and Hildreth, 1978); F, Shear zone separating Wyoming and Colorado provinces (Hills and others, 1968); G, Hinge line bounding northern margin of Uinta basin (Hansen, 1965); H, Willow Creek fault (Harrison, 1972); I, Hinge line bounding east side of Belt basin (Harrison, 1972); J, Coeur d'Alene trough (Harrison, 1972); K, Faults bounding Stillwater block (Page, 1977). 
approximately 1,400 and 1,000 m.y. ages. Many of the faults were repeatedly reactivated in Phanerozoic time.

About 1,600 m.y. ago the southern one-third of Wyoming moved vertically relative to the area to the north (Peterman and Hildreth, 1978). Movement on this fault zone (fig. 6, E) was undoubtedly a controlling factor in the deposition and preservation of the early Proterozoic sediments in this region.

A shear zone separates the Archean province of Wyoming from the middle Proterozoic rocks of southeastern Wyoming and Colorado (fig. 6, F). Hills and Houston (1979) suggested that the present shear zone marks the location of a collision between an Atlantictype continental margin and a volcanic arc about 1,700 m.y. ago.

The post-1,700 m.y. supracrustal sediments were deposited in basins controlled, at least in part, by vertical movements along faults in the older crust. Although sedimentation in the Rocky Mountain region proceeded more or less continuously for hundreds of millions of years, local events in individual basins apparently were not synchronous (pl. 1). The rapid subsidence at the Uinta basin (Hansen, 1965) seems to require a sharp time hinge line or fault (fig. 6, G). The Willow Creek fault (fig. $6, \mathrm{H}$ ) bounded a part of the Belt basin during early deposition of coarse clastics carried northward from the older Precambrian terrane about 1,500 m.y. ago, and subsidence along a basin margin hinge line (fig. 6, I) as well as minor faulting and subsidence of a basinal trough (fig. 6 , J) has been discussed by Harrison (1972). The basinal trough not only was active during Belt sedimentation but also was part of a zone of extensive shear and high-angle faults known as the Lewis and Clark line, along which movement has occurred intermittently at least through the Tertiary (Harrison and others, 1974).

\section{SUMMARY}

The earliest events in the Precambrian history of the Rocky Mountain region are ill defined, and much more work is needed to establish a time framework. In southern Montana and probably in northern Wyoming, silicic rocks existed well before 3,000 m.y. ago. Sediments derived from this ancient source seem to have been metamorphosed as early as 3,100 m.y. ago. In southern Montana, this metamorphism was followed by an intense metamorphic and plutonic episode, including emplacement of the Stillwater Complex at about 2,700 m.y. ago. Sedimentation may have occurred between 2,700 and 3,100 m.y. ago.

An earlier period (or periods) of regional metamorphism is dated between 2,800 and 3,000 m.y. in the Bighorn Mountains, Laramie Mountains, Granite Moun- tains, and Teton Range. The apparent absence of this event elsewhere may be due to a lack of data. Periods of granitic plutonism in central Wyoming are well defined in the interval of 2,550-2,650 m.y. ago. In the southeastern Wind River Range, the 2,650-m.y. age of the Louis Lake batholith is a minimum age for the economically important greenstone belt of the South Pass region. Present data do not provide an unequivocal age for the greenstone belt, but it may have been metamorphosed approximately $100 \mathrm{~m}$.y. earlier.

Gneiss and granite in southern Wyoming have commonly yielded ages 100 to $150 \mathrm{~m}$.y. younger than similar rocks in central Wyoming. Whether these ages indicate a true decrease in age of events to the south or are the result of later metamorphism is uncertain. Three analytically precise ages of 2,360 m.y., 2,420 m.y., and 2,500 m.y. for the same geologic unit, the Baggot Rocks Granite, in southern Wyoming, suggest that several geologic problems have not been fully resolved. At best, two of the three ages are wrong; possibly all have been lowered as a consequence of nearby events during the early and middle Proterozoic.

The predominance of metasedimentary rocks in southwestern Montana, the character of the Red Creek Quartzite in northeastern Utah, and the possibly Archean metasedimentary rocks in the Laramie Mountains all suggest the possibility of sedimentation around the margins of the Wyoming province in late Archean time. In any case, at least the southern and eastern margins were the site of thick accumulations of shelftype sediments in early Proterozoic time.

In part contemporaneous with this shelf-type sedimentation on the flank of the Archean craton, the continent in Colorado was being formed by the accumulation of volcanic and sedimentary rocks. Regional metamorphism of these rocks took place 1,700 m.y. ago; they were intruded by granitic rocks at 1,670, 1,4001,430 , and again at 1,015 m.y. ago.

Exactly what was happening to the west of the Wyoming craton during Proterozoic time is less clear, but fragmentary evidence is beginning to suggest at least some temporal correlations with events in Colorado. After about 1,500 m.y. ago, thick shelf sediments began to accumulate along the western margin of the now greatly expanded craton. This sedimentation continued intermittently into the Paleozoic.

\section{REFERENCES CITED}

Abbott, J. T., 1962, Rb-Sr study of isotopic redistribution in a Precambrian mylonite-bearing shear zone, northern Front Range, Colorado: Geological Society of America Bulletin, v. 83, p. 487493. 
Armstrong, R. L., 1968, Mantled gneiss domes in the Albion Range, southern Idaho: Geological Society of America Bulletin, v. 79, p. 1295.

1975, Precambrian (1500 m.y. old) rocks of central Idaho-The Salmon River arch and its role in Cordilleran sedimentation and tectonics: American Journal of Science, v. 275-A, p. 437-467.

Armstrong, R. L., and Hills, F. A.; 1967, Rb-Sr and K-Ar geochronologic studies of mantle gneiss domes, Albion Range, southern Idaho, U.S.A.: Earth and Planetary Science Letters, v. 3, p. 114-124.

Arth, J. G., Barker, F., and Stern, T. W., 1979, Geochronology of Archean gneisses in the Lake Helen area, southwestern Big Horn Mountains, Wyoming: Precambrian Research, v. 11, p. 1122.

Banks, P. O., and Heimlich, R. A., 1976, U-Pb ages of the Precambrian basement complex, Big Horn Mountains, Wyoming: Geological Society of America Abstracts with Programs, v. 8, p. 462.

Barker, Fred, 1969, Precambrian geology of the Needle Mountains, southwestern Colorado: U.S. Geological Survey Professional Paper 644-A, $35 \mathrm{p}$.

Barker, Fred, Hedge, C. E., Millard, H. T., Jr., and O'Neil, J. R., 1976, Pikes Peak batholith-Geochemistry of some minor elements and isotopes, and implications for magma genesis: Colorado School of Mines Professional Contributions 8, p. 44-56.

Bayley, R. W., 1968, Geologic map of the Bradley Peak quadrangle, Carbon County, Wyoming: U.S. Geological Survey Geologic Quadrangle Map GQ-773.

Bayley, R. W., Proctor, P. D., and Condie, K. C., 1973, Geology of the South Pass Area, Fremont County, Wyoming: U.S. Geological Survey Professional Paper 793, $39 \mathrm{p}$.

Bickford, M. E., and Cudzilo, T. F., 1975, U-Pb age of zircon from Vernal Mesa-type quartz monzonite, Unaweep Canyon, westcentral Colorado: Geological Society of America Bulletin, v. 86, p. 1432.

Bickford, M. E., Wetherill, G. W., Barker, Fred, and Lee-Hu, ChinNan, 1969, Precambrian Rb-Sr chronology in the Needle Mountains, southeastern Colorado: Journal of Geophysical Research, v. 74 , p. $1660-1676$.

Bryant, Bruce, and Hedge, C. E., 1978, Granite of Rosalie Peak, a phase of the 1700-million-year-old Mount Evans Pluton, Front Range, Colorado: U.S. Geological Survey Journal of Research, v. 6, p. $447-451$.

Campbell, F. A., Ethier, V. G., Krouse, H. R., and Both, R. A., 1978, Isotopic composition of sulfur in the Sullivan orebody, British Columbia: Economic Geology, v. 73, no. 2, p. 246-268.

Catanzaro, E. J., and Kulp, J. L., 1964, Discordant zircon from the Little Belt (Montana), Beartooth (Montana), and Santa Catalina (Arizona) Mountains: Geochimica et Cosmochimica Acta, v. 28, p. 87-184.

Chevillon, C. V., 1977, Tectonically induced, Proterozic soft sediment deformation at the Atlas property, Coeur d'Alene mining district, Idaho: Geological Society of America Abstracts with Programs, v. 9, p. 916.

Clark, S. H. B., 1973, Interpretation of a high-grade Precambrian terrane in northern Idaho: Geological Society of America Bulletin, v. 84, p. 1999-2003.

Compton, R. R., Todd, V. R., Zartman, R. E., and Naeser, C. W. 1977, Oligocene and Miocene metamorphism, folding and lowangle faulting in northwestern Utah: Geological Society of America Bulletin, v. 88, p. 1237.

Condie, K. C., 1969, Geologic evolution of the Precambrian rocks in northern Utah and adjacent areas: Utah Geological Survey Bulletin 82, p. 71-95.
Crittenden, M. D., Jr., and Peterman, Z. E., 1975, Provisional Rb/Sr age of the Precambrian Uinta Mountain Group, northeastern Utah: Utah Geology, v. 2, no. 1, p. 75-77.

Divis, A. F., 1976, Geology and geochemistry of Sierra Madre Range, Wyoming: Colorado School of Mines Quarterly, v. 71, no. 3, 127 p.

Doe, B. R., and Pearson, R. L., 1969, U-Th-Pb chronology of zircons from the St. Kevin Granite, northern Sawatch Range, Colorado: Geological Society of America Bulletin, v. 80, p. 2495.

Eby, D. E., 1977, Syndepositionally deformed voids as aids to regional correlation in the Helena Formation, Belt Supergroup, northwest Montana: Geological Society of America Abstracts with Programs, v. 9, p. 721

Edmunds, F. R., 1973, Depositional features of the lower Purcell Supergroup, British Columbia: Geological Association of Canada Programme and Abstracts, Cordilleran Section, p. 8-9.

Engel, A. E. J., 1963, Geologic evolution of North America: Science, v. 140 , p. 143.

Evans, K. V., 1981, U-Th-Pb zircon geochronology of Proterozoic $Y$ intrusions in the Salmon River area, east-central Idaho: Geological Society of America Abstracts with Programs, v. 13, no. 4, p. 195.

Frarey, M. H., and Roscoe, S. M., 1970, The Huronian Supergroup north of Lake Huron, in Baer, A. J., ed., Symposium on basins and geosynclines of the Canadian Shield: Geological Survey of Canada Paper 70-90, p. 143-158.

Goldich, S. S., Lidiak, E. G., Hedge, C. E., and Walthall, F. G., 1966, Geochronology of the Midcontinent Region, United States, Part II, northern area: Journal of Geophysical Research, v. 71, p. $5389-5408$.

Goodwin, A. M., 1977, Archean basin-craton complexes and the growth of Precambrian shields: Canadian Journal of Earth Sciences, v. 14, p. 2737-2759.

Graff, P. J., and Houston, R. S., 1977, Radioactive conglomerate in Proterozoic (Precambrian rocks) metasedimentary rocks of the Sierra Madre, Wyoming: U.S. Geological Survey Open-File Report 77-830, $7 \mathrm{p}$.

Graff, P. J., Sears, J. W., Holden, G. S., and Hausel, W. D., 1982 Geology of the Elmers rock greenstone belt, Laramie Range, Wyoming: Geological Survey of Wyoming Report of Investigations $14,23 \mathrm{p}$.

Granath, J. W., 1975, Wind River Canyon-An example of a greenstone belt in the Archean of Wyoming, U.S.A.: Precambrian Research, v. 2, p. 71-91.

Hansen, W. R., 1965, Geology of the Flaming Gorge area, Utah-Colorado-Wyoming: U.S. Geological Survey Professional Paper 490, $196 \mathrm{p}$.

Hansen, W. R., and Peterman, Z. E., 1968, Basement-rock geochronology of the Black Canyon of the Gunnison, Colorado: U.S. Geological Survey Professional Paper 600-C, p. C80-C90.

Harrison, J. E., 1972, Precambrian Belt Basin of northwestern United States-Its geometry, sedimentation and copper occurrence: Geological Society of America Bulletin, v. 83, p. 12151240.

1974, Copper mineralization in miogeosynclinal clastics of the Belt Supergroup, northwestern United States: Centenaire de la Société Géologique de Belgique Gisements Stratiformes et Provinces Cuprifères, Liege, 1974, p. 353-366.

Harrison, J. E., Griggs, A. B., and Wells, J. D., 1974, Tectonic features of the Precambrian Belt basin and their influence on postBelt structures: U.S. Geological Survey Professional Paper 866, $15 \mathrm{p}$.

Harrison, J. E., and Reynolds, M. W., 1976, Western U.S. continental margin-A stable platform dominated by vertical tectonics 
in the late Precambrian: Geological Society of America Abstracts with Programs, v. 8, p. 905.

Hedge, C. E., 1970, Whole-rock age of the Pikes Peak batholith, Colorado: U.S. Geological Survey Professional Paper 700-B, p. B86-B89.

Hedge, C. E., Peterman, Z. E., and Braddock, W. A., 1967, Age of the major Precambrian metamorphism in the northern Front Range, Colorado: Geological Society of America Bulletin, v. 78, p. 551-558.

Hedge, C. E., Peterman, Z. E., Case, J. E., and Obradovich, J. D., 1968, Precambrian geochronology of the northwestern Uncompahgre Plateau, Utah and Colorado: U.S. Geological Survey Professional Paper 600-C, p. C91-C96.

Heimlich, R. A., and Banks, P. O., 1968, Radiometric age determinations, Bighorn Mountains, Wyoming: American Journal of Science, v. 226, p. 180-192.

Hills, F. A., 1977, Uranium and thorium in the middle Precambrian Estes Conglomerate, Nemo District, Lawrence County, South Dakota - a preliminary report: U.S. Geological Survey Open-File Report 77-55, $12 \mathrm{p}$.

Hills, F. A., and Armstrong, R. L., 1974, Geochronology of Precambrian rocks in the Laramie Range and implications for the tectonic framework of Precambrian of southern Wyoming: Precambrian Research, v. 1, p. 213-225.

Hills, F. A., Gast, P. W., Houston, R. S., and Swainbank, I. G., 1968, Precambrian geochronology of the Medicine Bow Mountains, southeastern Wyoming: Geological Society of America Bulletin, v. 79, p. 1757-1784.

Hills, F. A., and Houston, R. S., 1979, Early Proterozoic tectonics of the central Rocky Mountains, North America: Contributions to Geology, v. 17, p. 89-109.

Hobbs, S. W., Griggs, A. B., Wallace, R. E., and Campbell, A. B. 1965, Geology of the Coeur d'Alene district, Shoshone County, Idaho: U.S. Geological Survey Professional Paper 478, 139 p.

Houston, R. S., Karlstrom, K. E., and Graff, P. J., 1977, Preliminary report on radioactive conglomerate of middle Precambrian age in the Sierra Madre and Medicine Bow Mountains of southeastern Wyoming: U.S. Geological Survey Open-File Report 77-574, $13 \mathrm{p}$.

Houston, R. S., and others, 1968, A regional study of rocks of Precambrian age in that part of the Medicine Bow Mountains lying in southeastern Wyoming-with a chapter on the relationship between Precambrian and Laramide structure: Wyoming Geological Survey Memoir 1, $167 \mathrm{p}$.

Houston, R. S., Schuster, J. E., and Ebbett, B. E., 1975, Preliminary report on the distribution of copper and platinum group metals in mafic igneous rocks of the Sierra Madre, Wyoming: U.S. Geological Survey Open-File Report 75-85, 129 p.

Hrabar, S. V., 1971, Stratigraphy and depositional environments of the St. Regis Formation of the Ravalli Group (Precambrian Belt Megagroup), northwestern Montana and Idaho: Cincinnati, Ohio, Cincinnati University $\mathrm{Ph}$. D. dissertation, $188 \mathrm{p}$.

Hutchinson, R. M., 1976, Granite-tectonics of the Pikes Peak batholith: Colorado School of Mines Professional Contributions 8 , p. $32-43$.

Hutchinson, R. M., and Hedge, C. E., 1967, Precambrian basement rocks of the central Colorado Front Range-their 700-millionyear history: Geological Society of America Rocky Mountain Section Guidebook for Field Trip 1, 51 p.

Izett, G. A., 1968, Geology of the Hot Sulphur Springs quadrangle, Grand County, Colorado: U.S. Geological Survey Professional Paper 586, $79 \mathrm{p}$.

James, H. L., 1954, Sedimentary facies of iron formation: Economic Geology, v. 49, p. 235-293.
James, H. L., and Hedge, C. E., 1980, Age of the basement rocks of southwest Montana: Geological Society of America Bulletin, v. 91, p. $11-15$.

Johnson, R. C., and Hills, F. A., 1976, Precambrian geochronology and geology of the Box Elder Canyon area, northern Laramie Range, Wyoming: Geological Society of America Bulletin, v. 87, p. $809-817$.

Karlstrom, K. E., and Houston, R. S., 1978, Stratigraphy and uranium potential of the Deep Lake Group, Medicine Bow Mountains, Wyoming: Geological Survey of Wyoming R1-13, $30 \mathrm{p}$.

Kleinkopf, M. D., and Redden, J. A., 1975, Bouguer gravity, aeromagnetic, and generalized geologic maps of part of the Black Hills of South Dakota and Wyoming: U.S. Geological Survey Geophysical Investigations Map GP-903.

Knight, S. H., and Keefer, D. K., 1966, Preliminary report on the Precambrian stromatolites in the Nash Formation, Medicine Bow Mountains, Wyoming: Contributions to Geology, v. 5, p. 1-11.

Ludwig, K. R., and Stuckless, J. S., 1978, Uranium-lead isotope systematics and apparent ages of zircons and other minerals in Precambrian granitic rocks, Granite Mountains, Wyoming: Contributions to Mineralogy and Petrology, v. 65, p. 243-254.

Marsh, S. P., and Sheridan, D. M., 1976, Rutile in Precambrian sillimanite-quartz gneiss and related rocks, east-central Front Range, Colorado: U.S. Geological Survey Professional Paper 959-G, $17 \mathrm{p}$.

McCallum, M. E., and Hedge, C. E., 1976, Rb-Sr ages of granitic rocks in the Rawah batholith, Medicine Bow Mountains, northern Colorado: Isochron/West 17, p. 33-37.

Mueller, P. A., and Cordua, W. S., 1976, Rb-Sr whole rock age of gneisses from the Horse Creek area, Tobacco Root Mountains, Montana: Isochron/West 16, p. 33-36.

Mueller, P. A., Odom, A. L., and Larsen, L. H., 1976, Archean history of the eastern Beartooth Mountains, Montana: Geological Society of America Abstracts with Programs, v. 8, p. 810 .

Naylor, R. S., Steiger, R. H., and Wasserburg, G. J., 1970, U-Th-Pb and $\mathrm{Rb}-\mathrm{Sr}$ systematics of $2700 \times 10^{6}$ year old plutons from the southern Wind River Range, Wyoming: Geochimica et Cosmochimica Acta, v. 34, p. 1133-1159.

Nunes, P. D., and Tilton, G. R., 1971, Uranium-lead ages of minerals from the Stillwater igneous complex and associated rocks, Montana: Geological Society of America Bulletin, v. 82, p. 2231-2250.

Olson, J. C., Marvin, R. F., Parker, R. L., and Mehnert, H. H., 1977, Age and tectonic setting of lower Paleozoic mafic rocks, carbonatites, and thorium veins in south-central Colorado: U.S. Geological Survey Journal of Research, v. 5, no. 6, p. 673-687.

Page, N. J., 1977, Stillwater Complex, Montana-Rock succession, metamorphism and structure of the complex and adjacent rocks: U.S. Geological Survey Professional Paper 999, 79 p.

Peterman, Z. E., 1981, Archean gneisses in the Little Rocky Mountains, Montana, chapter A in Shorter contributions to isotope research in the Western United States, 1980: U.S. Geological Survey Professional Paper 1199, p. 1-6.

-1982, Geochronology of the southern Wyoming age province-a summary: 1982 Archean Geochemistry Field Conference, part 1, Guide to Field Trips, p. 1-23.

Peterman, Z. E., Hedge, C. E., and Braddock, W. A., 1968, Age of Precambrian events in the northeastern Front Range, Colorado: Journal of Geophysical Research, v. 73, p. 2277-2296.

Peterman, Z. E., and Hildreth, R. A., 1978, Reconnaissance geology and geochronology of the Precambrian of the Granite Mountains, Wyoming: U.S. Geological Survey Professional Paper 1055, 22 p.

Redden, J. A., and Norton, J. J., 1975, Precambrian geology of the Black Hills, in Mineral and water resources of South Dakota: South Dakota Geological Survey Bulletin, v. 12, p. 21-28. 
Reed, J. C., Jr., and Zartman, R. E., 1973, Geochronology of the Precambrian rocks of the Teton Range, Wyoming: Geological Society of America Bulletin, v. 84, p. 561-582.

Reid, R. R., McMannis, W. J., and Palmquist, J. C., 1975, Precambrian geology of the North Snowy block, Beartooth Mountains, Montana: Geological Society of America Special Paper 157, 135 p.

Reid, R. R., Morrison, D. A., and Greenwood, W. R., 1973, The Clearwater orogenic zone-A relict of the Proterozoic orogeny in central and northern Idaho, in Belt Symposium: Idaho Bureau of Mines and Geology Special Publication, v. 1, p. 10-56.

Riley, G. H., 1970, Isotopic discrepancies in zoned pegmatites, Black Hills, South Dakota: Geochimica et Cosmochimica Acta, v. 34, p. 713-725.

Roscoe, S. M., 1973, The Huronian Supergroup, a Paleoaphebian succession showing evidence of atmospheric evolution: Geological Association of Canada Special Paper 12, p. 31-48.

Ruppel, E. T., 1975, Precambrian Y sedimentary rocks in east-central Idaho: U.S. Geological Survey Professional Paper 889-A, 23 p.

Rye, D. M., Doe, B. R., and Delevaux, M. H., 1974, Homestake gold mine, South Dakota-II, Lead isotopes, mineralization ages and source of lead in ores of the northern Black Hills: Economic Geology, v. 69, p. 814-822.

Scott, G. R., Taylor, R. B., Epis, R. C., and Wobus, R. A., 1976 Geologic map of the Pueblo $1^{\circ} \times 2^{\circ}$ quadrangle, south-central Colorado: U.S. Geological Survey Miscellaneous Field Studies Map MF-775.

Sheridan, D. M., and Raymond, W. H., 1977, Preliminary data on some Precambrian deposits of zinc-copper-lead sulfides and zinc spinel (gahnite) in Colorado: U.S. Geological Survey Open-File Report 77-607, $27 \mathrm{p}$

Silver, L. T., and Barker, F., 1968, Geochronology of Precambrian rocks in the Needle Mountains, southwestern Colorado, part 1 , $\mathrm{U}-\mathrm{Pb}$ zircon results [abs.]: Geological Society of America Special Paper 115, p. 204.

Snyder, G. L., 1980, Map of Precambrian and adjacent Phanerozoic rocks of the Hartville Uplift, Goshen, Niobrara, and Platte Counties, Wyoming: U.S. Geological Survey Open-File Report 80-779, 11 p., 2 sheets.

Snyder, G. L., and Hedge, C. E., 1978, Intrusive rocks northeast of Steamboat Springs, Park Range, Colorado: U.S. Geological Survey Professional Paper 1041, 42 p.

Snyder, G. L., and Peterman, Z. E., 1982, Precambrian geology and geochronology of the Hartville uplift, Wyoming: 1982 Archean Geochemistry Field Conference, Part 1, Guide to Field Trips, p. 64-94.

Spencer, A. C., 1904, The copper deposits of the Encampment District, Wyoming: U.S. Geological Survey Professional Paper 25, $107 \mathrm{p}$.

Stacey, J. S., Zartman, R. E., and Nkomo, I. T., 1968, A lead isotope study of galenas and selected feldspars from mining districts in Utah: Economic Geology, v. 63, p. 796-814.
Stern, T. W., Phair, George, and Newell, M. F., 1971, Boulder Creek Batholith, Colorado, part II, Isotopic age of emplacement and morphology of zircon: Geological Society of America Bulletin, v. 82 , p. $1615-1634$.

Stewart, J. H., 1976, Late Precambrian evolution of North America-Plate tectonics implication: Geology, v. 4, p. 11-15.

Stueber, A. M., and Heimlich, R. A., 1977, Rb-Sr isochron age of the Precambrian basement complex, Big Horn Mountains, Wyoming: Geological Society of America Bulletin, v. 88, p. 441444.

Subbarayudu, G. V., Hills, F. A., and Zartman, R. E., 1975, Age and $\mathrm{Sr}$ isotopic evidence for the origin of the Laramie anorthosite-syenite complex, Laramie Range, Wyoming: Geological Society of America Abstracts with Programs, v. 7, p. 1287.

Tweto, Ogden, 1960, Scheelite in the Precambrian gneisses of Colorado: Economic Geology, v. 55, p. 1406-1428.

1968, Geologic setting and interrelationships of mineral deposits in the mountain province of Colorado and south-central Wyoming, in Ore deposits of the United States, 1933-1967, Volume 1: American Institute of Mining, Metallurgical and Petroleum Engineers, p. 551-588.

1977, Nomenclature of Precambrian rocks in Colorado: U.S. Geological Survey Bulletin 1422-D, 22 p.

-1979 , Geologic map of Colorado: U.S. Geological Survey, Special Geologic Map, scale 1:500,000.

Tweto, Ogden, and Sims, P. K., 1963, Precambrian ancestry of the Colorado mineral belt: Geological Society of America Bulletin, v. 74, p. 991-1014.

Wallace, C. A., and Crittenden, M. D., Jr., 1969, The stratigraphy, depositional environment, and correlation of the Precambrian Uinta Mountain Group, western Uinta Mountains, Utah, in Lindsay, J. B., ed., Geologic guidebook of the Uinta Mountains, Utah's maverick range: Intermountain Association of Geologists 16th Annual Field Conference, p. 126-141.

Whelan, J. F., 1969, Geochronology of some Utah rocks, in Guidebook of northern Utah: Utah Geological and Mineralogical Survey Bulletin 82, p. 97-104.

Winston, Donald, 1973, The Bonner Formation as a Late Precambrian pediplain: Northwest Geology, v. 2, p. 53-58.

Wobus, R. A., 1976, New data on potassic and sodic plutons of the Pikes Peak batholith, central Colorado: Colorado School of Mines Professional Contributions 8, p. 57-67.

Young, E. V., 1975, An occurrence of disseminated uraninite in Wheeler Basin, Grand County, Colorado: U.S. Geological Survey Journal of Research, v. 3, no. 3, p. 305-311.

Young, E. V., and Sims, P. K., 1961, Petrography and origin of xenotime and monazite concentrations, Central City district, Colorado: U.S. Geological Survey Bulletin 1032-F, p. 273-299.

Zartman, R. E., Norton, J. J., and Sterns, T. W., 1964, Ancient granite gneiss in the Black Hills, South Dakota: Science, v. 145, p. $479-481$.

Zartman, R. E., and Stacey, J. S., 1971, Lead isotopes and mineralization ages in the Belt Supergroup rocks, northwestern Montana and northern Idaho: Economic Geology, v. 66, p. 849-860. 